\title{
Oxide Formation on NiTi Surface: Influence of the Heat Treatment Time to Achieve the Shape Memory
}

\author{
Alana Witt Hansen ${ }^{a}$, Lilian Vanessa Rossa Beltrami ${ }^{a *,}$ Leonardo Marasca Antonini, \\ Denis Jardim Villarinho ${ }^{b}$, Julio Cesar Klein das Neves', Cláudia Eliana Bruno Marino ${ }^{d}$, \\ Célia de Fraga Malfatti
}

\author{
${ }^{a}$ Laboratório de Pesquisa em Corrosão - LAPEC, Universidade Federal do Rio Grande do Sul- \\ UFRGS, Av. Bento Gonçalves, 9500, Bloco 4, Prédio 75, 2 andar, Bairro Agronomia, \\ CEP 91501-970, Porto Alegre, RS, Brazil \\ ${ }^{b}$ Instituto de Ciências Exatas e Tecnológicas - ICET, Universidade Feevale, Av. Dr. Maurício Cardoso, \\ 510, Bairro Hamburgo Velho, CEP 93510-250, Novo Hamburgo, RS, Brazil \\ 'Departamento Acadêmico de Mecânica, Universidade Tecnológica Federal do Paraná-UTFPR, \\ Av. Sete de Setembro, 3165, Bloco L, 4 andar, Bairro Rebouças, CEP 80230-901, Curitiba, PR, Brazil \\ ${ }^{d}$ Departamento de Engenharia Mecânica, Universidade Federal do Paraná - UFPR, \\ Av. Coronel Francisco Heráclito dos Santos, s/n, Bloco IV, Centro Politécnico-Campus II, \\ Bairro Jardim das Margaridas, CEP 81531-981, Curitiba, PR, Brazil
}

Received: July 16, 2015; Revised: September 12, 2015

\begin{abstract}
Several studies regarding superficial treatments of Nitinol (NiTi) shape-memory have been developed aiming to the improve corrosion resistance and to block the Ni release to adjacent tissues. The necessary heat treatment to achieve the shape memory effect normally occurs at temperatures between 500 and $600{ }^{\circ} \mathrm{C}$. However, titanium oxide $\left(\mathrm{TiO}_{2}\right)$ is formed on the NiTi surface during the shape memory process heat treatment. In this work the effects of the heat treatment time on the surface characteristics of the formed NiTi oxide, at temperatures that promote the shape-memory $\left(530\right.$ and $\left.570{ }^{\circ} \mathrm{C}\right)$, were evaluated. The $\mathrm{TiO}_{2}$ layers which were obtained were evaluated by X-ray diffraction (XRD), energy dispersive X-ray (EDX), scanning electron microscope (SEM), thermogravimetric analysis (TGA), wettability and roughness. The results show that by increasing the exposure time at the temperature of $570{ }^{\circ} \mathrm{C}$ the formation of a thicker oxide is promoted, with less superficial roughness and of a hydrophobic nature. According to the literature, these characteristics indicate that the obtained oxide layer has properties that accelerat the osseointegration process.
\end{abstract}

Keywords: biomaterial, NiTi, shape-memory, heat treatment, oxide

\section{Introduction}

NiTi alloys have been used in various devices in medicine and dentistry, in general due to its super elasticity and its shape memory effect ${ }^{1}$. The shape memory alloys are functional materials, which have the ability to recover plastic deformation via a suitable thermal condition ${ }^{2}$.

The heat treatment necessary to achieve the shape memory effect normally occurs at temperatures between 500 and $800{ }^{\circ} \mathrm{C}$. The most commonly used treatments are annealing and normalization, consisting of subjecting the alloy to temperatures between $500{ }^{\circ} \mathrm{C}$ and $650{ }^{\circ} \mathrm{C}$ for a short time interval, and after exposing to cooled air or in the oven with an inert gas stream ${ }^{3}$. These heat treatments at moderate temperatures are intended to induce relaxation of the material, avoiding permanent deformation and maintaining its superplastic behavior ${ }^{4}$. The main advantage of heat treatment in NiTi alloys with shape memory effect is a decrease in stiffness.

*e-mail: lvrossa@yahoo.com.br
In the biological environment, titanium is well tolerated by the tissues, providing great biomedical and dental applications ${ }^{5}$. Pure nickel is a used metal alloy because of its flexibility and low melting points, characteristics that confer to the NiTi alloy to a modulus of elasticity close to that of bone. However, Ni ions are classified as carcinogenic chemica ${ }^{6}$.

When exposed to air, titanium and its alloys spontaneously form a continuous and adherent film, which in contact with biological fluids make it very biocompatible ${ }^{7}$. Both the thickness and the chemical composition of the titanium oxide layer are important in the adsorption of proteins from biological fluids. However, the spontaneously formed oxide layer on the titanium surface is not ideal because it is heterogeneous and thin, thereby hindering the chemical bonding of the implant to the bone ${ }^{8}$. Therefore, increasing the thickness of this oxide is considered an alternative for improving the adhesion and the biocompatibility of this material.

Lautenschlager ${ }^{9}$ cites that $\mathrm{TiO}_{2}$ is very impervious to oxygen at ambient temperature and its layer at that temperature 
has only 5 to 20 carbon atoms. Under these conditions the layer is strongly adhered to the substrate. However, severe temperature conditions alter the stresses developed during the process and consequently influence the protective capacity of the oxide layer. The adhesion decreases with increasing temperatures and with increasing layer thickness.

$\mathrm{Xu}$ et al. ${ }^{10}$ studied the isothermal oxidation behavior of a commercial $50 \% \mathrm{NiTi}$ alloy with shape memory in a pure oxygen atmosphere in a temperature ranging from 450 to $750{ }^{\circ} \mathrm{C}$. The authors found that the oxidation kinetics of this alloy obeys the parabolic law and that the energy of the titanium oxide formation activation is $133 \mathrm{~kJ} . \mathrm{mol}^{-1}$. The authors affirm that the formation of the oxide layer is controlled primarily by diffusion of Ti alloy through the oxide.

In the study by Firstov et al. ${ }^{11}$, NiTi samples (50\% Ni) were polished subjected to a heat treatment in air, and in a temperature range from 300 to $800{ }^{\circ} \mathrm{C}$. The results showed that at temperatures between 500 and $600{ }^{\circ} \mathrm{C}$ the formation of a $\mathrm{TiO}$ layer was covered by a thin $\mathrm{TiO}_{2}$ layer. According to the authors, these formed layers are homogeneous and protective, but with a slow speed training. Between 600 and $800{ }^{\circ} \mathrm{C}$ there is the formation of a layer of $\mathrm{TiO}_{2}$ on a layer of $\mathrm{NiTiO}_{3}$. This oxide has a rough surface and the formed layer is porous. Considering these results, the authors concluded that the oxide layer with properties suitable for use in implants must be obtained in an air atmosphere with temperatures between 500 and $600{ }^{\circ} \mathrm{C}$.

The importance of NiTi shape memory alloy is attested by the large number of researches of its use in applications, such as its application in biomaterials in surgical implants, considering the confirmed relationship between the biocompatibility with the presence of the oxide layer on its surface. The effect of heat treatment time on the formation of NiTi alloys, at temperatures of $530^{\circ} \mathrm{C}$ and of $570{ }^{\circ} \mathrm{C}$, was studied in order to evaluate the characteristics and properties of the obtained oxide layers.

\section{Methodology}

The commercial NiTi used in this work contains $55.8 \%$ of $\mathrm{Ni}$, as determined by fluorescence analysis equipment, of the brand Thermo Scientific, a Niton XL3t model. Each sample was cut into dimensions of $30 \mathrm{~mm} \times 4 \mathrm{~mm} \times 1 \mathrm{~mm}$ and was gradually abraded with $180-600 \mathrm{SiC}$ sandpaper in order to homogenize the topography of the surface and remove contamination.

Subsequently, the samples were heat treated at different temperatures in a muffle furnace in air atmosphere: $530{ }^{\circ} \mathrm{C}$ and $570{ }^{\circ} \mathrm{C}^{11-13}$. The samples were exposed to different heat treatment durations: $6,20,60,240$ and 480 minutes and thereafter the samples were characterized.

According to D. Vojtech et al. ${ }^{4}$, moderate temperatures (between 500 and $600^{\circ} \mathrm{C}$ ) maintain the superplastic behavior of the alloy and prevent permanent deformation, ensuring the integrity of the material required for the application. Table 1 presents the nomenclature used to identify each analyzed sample.

The TGA was performed with a 50-Shimadzu TGA instrument in a temperature range of 23 to $700{ }^{\circ} \mathrm{C}$, with
Table 1. Sample identification according to heat treatment parameters.

\begin{tabular}{ccc}
\hline Sample & Time $(\mathbf{m i n})$ & Temperature $\left({ }^{\circ} \mathbf{C}\right)$ \\
\hline NiTi530F6' & 6 & 530 \\
NiTi530F20' & 20 & \\
NiTi530F60' & 60 & \\
NiTi530F240' & 240 & \\
NiTi530F480' & 480 & 570 \\
NiTi570F6' & 6 & \\
NiTi570F20' & 20 & \\
NiTi570F60' & 60 & \\
NiTi570F240' & 240 & \\
NiTi570F480' & 480 & \\
\hline
\end{tabular}

a heating rate of $10^{\circ} \mathrm{C} \mathrm{min}^{-1}$ and under an airflow rate of $50 \mathrm{~mL} \mathrm{~min}^{-1}$.

The identification of the formed phases on the sample surface was obtained by low angle X-ray diffraction, performed by Shimadzu XRD-7000 equipment. Copper K $\alpha$ radiation was utilized, by applying an acceleration voltage of $40 \mathrm{kV}$ and a current of $25 \mathrm{~mA}$ to the X-ray tube. The primary X-ray beam reached sample surfaces at an inclination of 3 degrees above the horizontal plane.

The cross-section samples were analyzed by a Scanning Electron Microscopy (SEM) and Energy Dispersive X-ray (EDX) in a JEOL JSM 6060 SME to estimate the oxide layer thickness. Afterwards, the heat treated samples were analyzed by EDX in the same equipment to obtain the line profile analysis of the elemental composition for the oxide layer. A beam acceleration voltage of $20 \mathrm{kV}$ was used in both analyses.

Sample surface roughness was determined by a CETR-PRO5003D profilometer. Three areas were analyzed in each sample to determine the average roughness $(\mathrm{Ra})$. For this kind of analysis some geometric parameters should be specified, such as sample size, also known as cut off. These values were determined by the expected roughness as recommended by the ISO 4288 standard $^{14}$.

The surface wettability was determined by the sessile drop method in equipment developed in the Laboratory of Corrosion Research (LAPEC/ UFRGS). With this method it is possible to measure the contact angle goniometer, using an optical system to capture the profile of the liquid (water) on a surface substrate. Surface samples that were considered hydrophilic, had a surface contact angle smaller $90^{\circ}$. Surface samples that were considered hydrophobic, had a contact angle larger than $90^{\circ 15}$.

\section{Results and Discussion}

The thermogram shown in Figure 1 shows the evolution of mass gain with increasing temperature. It is observed that the increase in temperature causes a gradual and progressive, more pronounced, weight gain from $500{ }^{\circ} \mathrm{C}$. This behavior was also observed by Firstov et al. ${ }^{11}$, who suggests that the oxidation mechanism is different above and below $500{ }^{\circ} \mathrm{C}$. This result demonstrates that the increase in temperature 
promotes the oxidation process, increasing the diffusion rate and, hence, the mass gain.

Figures 2 and 3 show the XRD diffraction patterns for the heat treated NiTi samples, respectively, at $530{ }^{\circ} \mathrm{C}$ and $570{ }^{\circ} \mathrm{C}$ at different times of treatment. The energy of $\mathrm{TiO}_{2}$ formation is much greater when compared to the energy of $\mathrm{NiO}$ formation, which leads to preferential formation of $\mathrm{TiO}_{2}$ at the surface of NiTi when exposed to high temperatures ${ }^{16}$.

It is observed that both XRD patterns show very similar results. Initially, at 6 minutes of exposure to high temperatures, peaks relating to the NiTi substrate are present. By increasing

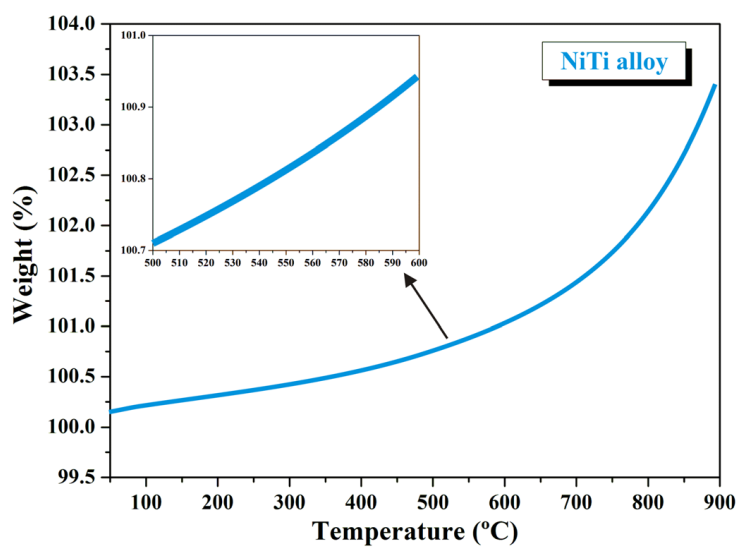

Figure 1. TGA of NiTi alloy with a heating rate of $10^{\circ} \mathrm{C} \cdot \mathrm{min}^{-1}$ under air and flow rate of $50 \mathrm{~mL} \cdot \mathrm{min}^{-1}$. the exposure time, the intensity decreased, indicating the presence of a layer that covers the surface of the substrate.

Even for samples with a shorter time exposure to high temperatures (NiTi530F6' and NiTi570F6') it is possible to observe the presence of peaks relating to the formation of the anatase crystalline phase of $\mathrm{TiO}_{2}$ whose characteristic peak of highest intensity is this phase is observed at $2 \theta$ about $25^{\circ}$. When the exposure time is increased, formation of the rutile phase of $\mathrm{TiO}_{2}$ occurs, with a gradual attenuation of the intensity of the peaks of the anatase phase. The formation of the rutile phase is evidenced by the formation and increase of the intensity of the peak at $2 \theta$ about $28^{\circ}$.

The $\mathrm{TiO}_{2}$ consists of $\mathrm{Ti}^{4+}$ ions in the center of an octahedron formed by six $\mathrm{O}^{2-i o n s . ~ T h e ~ r u t i l e ~ a n d ~ a n a t a s e ~ s t r u c t u r e s ~}$ differ by octahedrons formed by distortion of the oxygen atoms and the crystals are tetragonal symmetry. The unit cell contains four anatase $\mathrm{TiO}_{2}$, molecules, while the rutile has two molecules per unit cell. However, the structure of anatase is more elongated and has a larger volume than the rutile cell, therefore, the anatase is less dense than the rutile ${ }^{17}$.

These differences in the crystalline structure and arrangement result in a number of different properties for each phase. The NiTi is widely studied due to its biocompatibility with the human organism, since crystalline-structure oxides are more favorable to promoting the biocompatibility when compared to amorphous oxides ${ }^{18}$.

The rutile phase is thermodynamically more stable at high temperatures, whereas the metastable anatase phase is obtained only at low temperatures. The anatase phase

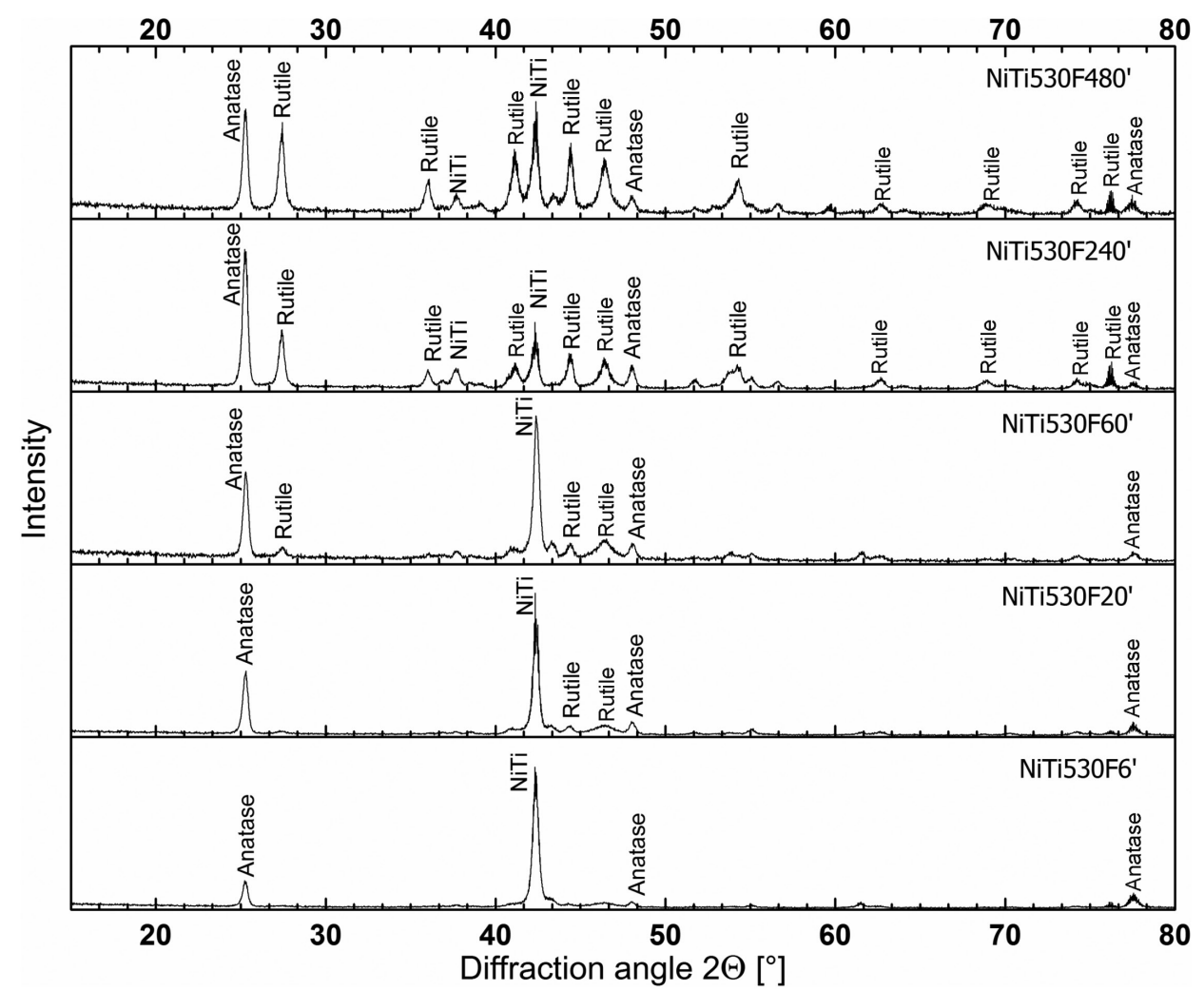

Figure 2. XRD patterns referents to $530{ }^{\circ} \mathrm{C}$ heat treated samples for $6,20,60,240$ and 480 minutes. 


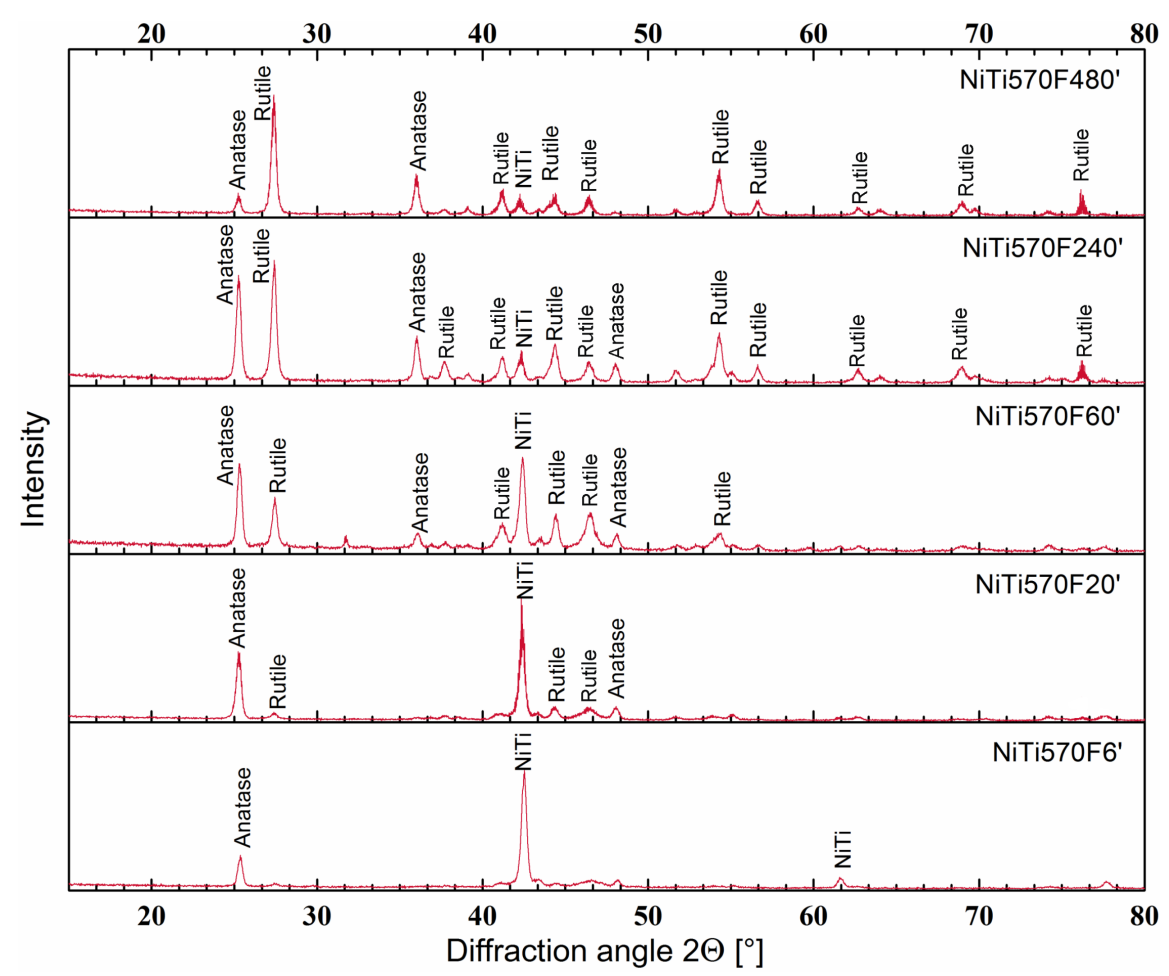

Figure 3. XRD patterns referents to $570{ }^{\circ} \mathrm{C}$ heat treated samples for $6,20,60,240$ and 480 minutes

is the most stable in the nanometer scale and the most studied in nanotechnology applications. Rutile has been used in various biomedical applications because it yields an osseointegration process ${ }^{19}$.

However, the phase change can promote the formation of various defects in the crystal lattice of the oxide. Intrinsic and extrinsic defects in the crystalline structures are strongly influenced by heat treatment in reducing and oxidizing atmospheres. In general, it is observed that the anatase structure defects are embedded near the surface, while in the rutile structure they are spread over the crystal lattice. Therefore, the defects in the structure of $\mathrm{TiO}_{2}$ are initially formed on the surface where they are most stable, where they equally cause the formation and the concentration of Ti ions.

Later, with the change in crystal structure, the defects, formed probably by oxygen vacancies, allow the diffusion of ions by the Ti reticulum through channels in the structure ${ }^{20}$. These ions migrate to the oxide surface and react to the oxygen in the air, promoting the formation of additional oxide. Figure 2. XRD patterns corresponding to heat treated samples at $530{ }^{\circ} \mathrm{C}$ for $6,20,60,240$ and 480 minutes.

Figure 4 shows the micrographs obtained by SEM at the cross section of the samples after the heat treatment, where can be seen the thickness of the formed oxide. It is observed that, for both temperatures and heat treatment times, the formed oxide appears homogeneous, compact and adhered to the metal substrate. The increase in heat treatment time promoted an increase in the thickness of the oxide layer formed on the surface. This result corroborates with the findings in Figure 1, where it is shown that the increase in heat treatment time enhances the diffusion rate, promoting weight gain and thus increasing the thickness of the layer.

Figure 5 shows the average thickness of the oxide layer formed at different temperatures, as measured by the SEM pictures. It is known that when NiTi alloy is exposed to air at ambient temperature, it forms a passive oxide layer on the surface of approximately $10 \mathrm{~nm}^{21}$. It is observed that for the time of 6 minutes of exposure, at both temperatures, the thickness of the oxide layer increased more than 100 fold, when compared to the formed oxide layer at room temperature.

The increased thickness of the formed oxide increases during the first 60 minutes of exposure and later growth has proved to be constant (considering deviations) for the remainder of the test for both samples.

The process controls the slower growth rate of an oxide. According to C.H. Xu et al. ${ }^{10}$ the decrease of the oxide formation rate can be related to the decrease in the rate of diffusion of the Ti responsible for the reaction speed.

As different temperatures were being assessed, it was observed that the oxide formed at $570{ }^{\circ} \mathrm{C}$ obtained a greater thickness compared to the oxide formed at $530^{\circ} \mathrm{C}$. This variation is explained by the exothermic nature of the reaction that occurs between metals and oxidizing agents, being thermodynamically favored by high temperatures, where there is a high free energy $\Delta \mathrm{G}$. The kinetics of reaction is favored by the high free energy $\Delta \mathrm{G}$ and the oxidation rate is considerably higher ${ }^{16}$, which promotes the formation of a thicker oxide layer.

Therefore, it can be observed that the growth mechanism of oxide, at both temperatures, is governed by the parabolic law, indicating that the diffusion process controls the growth 


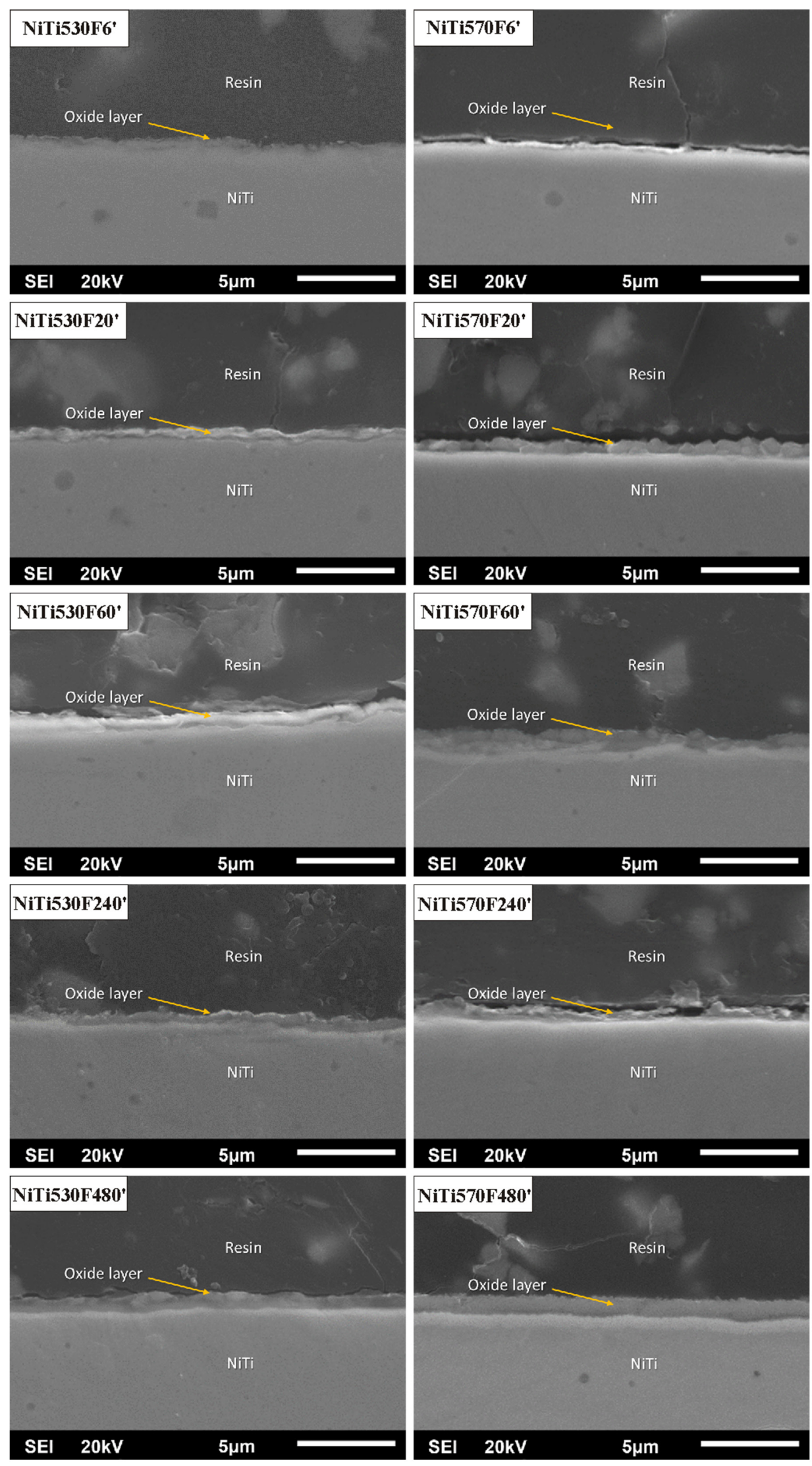

Figure 4. Cross section analyses obtained by SEM for the samples heat treated at $530^{\circ} \mathrm{C}$ and $570{ }^{\circ} \mathrm{C}$ for different times of heat treatment. 


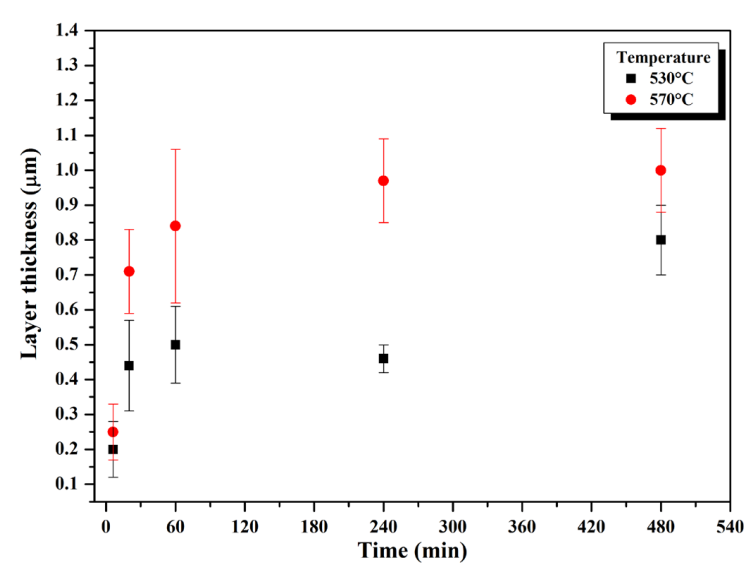

Figure 5. Graphical representation of oxide layer thickness $(\mu \mathrm{m})$ for all evaluated samples.

mechanism ${ }^{10}$. Oxides formed by such mechanisms tend to be compact, adherent and a controlled migration of ions. These are typical characteristics of protective oxides ${ }^{22}$.

The growth kinetics of the parabolic law states that the diffusion of ions through the oxide is controlled the growth rate is inversely proportional to the thickness of the oxide. Initially interfacial reaction controls the growth of oxidation and when the oxide thickness increases, the carrier material becomes the speed control mechanism of oxidation ${ }^{23}$. According to Ribbe et al. ${ }^{24}$, when titanium oxide is exposed to temperatures between $360^{\circ} \mathrm{C}$ and $850{ }^{\circ} \mathrm{C}$, it tends to form according to the kinetic parabolic law.

As seen in Figures 4 and 5, the increased thickness of the oxide and decrease and/or remain constant with increasing heat treatment time, due to the difficulty faced by Ti ions to diffuse in the thicker oxide layer. However, even with a thick layer, the oxide continues to form due to the diffusion of ions which is facilitated by the imperfections present in its crystal lattice. This is an important factor during the whole formation of the oxide, as in the case of $\mathrm{TiO}_{2}$, the crystalline network has excess interstitial Ti metal ions, which migrate during oxidation to the outer layer by reacting with oxygen in the air and promoting the forming of oxide ${ }^{25}$.

Figure 6 shows the EDX analysis results of the samples analyzed at different times of heat treatment. The dotted lines mark the observed metal interfaces/oxide/surface.

The presented spectra are very similar for both temperatures. Initially, with 6 minutes of exposure, there is the formation of an oxide layer with a higher concentration of titanium and, by increasing the exposure time, there is an increase in the oxide thickness. As discussed above and shown in Figures 4 and 5 , the highest temperature $\left(570{ }^{\circ} \mathrm{C}\right)$ caused further growth of the oxide, forming a thicker layer when compared to the oxide layer formed at $530{ }^{\circ} \mathrm{C}$.

It is known that Ti has a higher affinity with oxygen $\left(\mathrm{O}^{2-}\right)$, when compared to $\mathrm{Ni}$, as the change in Gibbs free energy $(\Delta \mathrm{G})$ is much lower than for $\mathrm{TiO}_{2}$ to the $\mathrm{NiO}$ (respectively $-889,1 \mathrm{~kJ} \mathrm{~mol}^{-1}$ and $211 \mathrm{~kJ} \mathrm{~mol}^{-1}$ ). Therefore, it is observed that with increasing time of exposure at moderate temperatures, the oxide formed is composed mainly of $\mathrm{TiO}_{2}$ with a slow formation and growth. In the samples exposed for 20 minutes
(NiTi530F20' and NiTi570F20') is observed a fraction of Ti and $\mathrm{Ni}$ very similar to the interface between the metal and the oxide. Thereafter, for samples exposed for 60 minutes (NiTi530F60' and NiTi570F60') is observed an increase of the Ti fraction in the oxide layer and, consequently, an enrichment of the $\mathrm{Ni}$ in the metal/oxide interface. It is noteworthy that this behavior remained progressive with increasing exposure time. In addition, for samples exposed to $570{ }^{\circ} \mathrm{C}$ the enrichment of the $\mathrm{Ni}$ in the metal/oxide interface was more pronounced.

These results show the existence of a migration phenomenon of Ti ions originating in NiTi substrate along the oxide to the oxide/surface interface. This migration causes a decrease of the Ti in the metal/oxide interface and, hence, a Ni enrichment at this location. Furthermore, the results show that at higher temperatures $\left(570^{\circ} \mathrm{C}\right)$ and the kinetics of the reaction rate is favored because the formed oxide has a greater enrichment of $\mathrm{Ti}$ ions when compared with the oxide formed at $530{ }^{\circ} \mathrm{C}$.

The Ni enrichment in the metal/oxide interface requires attention, because if the layer $\mathrm{TiO}_{2}$ is thin and/or contains cracks, $\mathrm{Ni}^{2-}$ ions may move to the surface, causing irreversible toxic effects due to their accumulation in tissues ${ }^{26}$. Therefore, the increased thickness of the $\mathrm{TiO}_{2}$ layer is very important because it acts as a physical barrier that effectively blocks the transport of ions to the $\mathrm{Ni}^{2-}$ surface ${ }^{27}$.

As shown in Figure 6, the increase in thermal treatment time, at both temperatures, promoted an increase in the concentration of $\mathrm{Ti}$ ions in the outermost layer formed of $\mathrm{TiO}_{2}$. This result corroborates the results observed by XRD analysis (Figures 2 and 3), because during this same period the oxide changes its crystal structure (the anatase to rutile phase), promoting the formation of lattice defects that promote the migration of Ti ions through the oxide to the surface.

Figure 7 shows the surface roughness values (a) and contact angle (b) of the surface of the NiTi samples at different periods of the heat treatment. It is noted that for both temperatures the surface roughness of the samples decreased with increasing time of heat treatment (Figure 7a). However, the samples exposed to $570{ }^{\circ} \mathrm{C}$ showed a more significant decrease in this parameter.

Figure $7 \mathrm{~b}$ shows that the contact angle values increased with an increase in the heat treatment time for both temperatures, indicating a decrease in surface wettability. It is also observed that the average of the contact angles is $\leq 90^{\circ}$ for all samples, indicating a hydrophilic behavior of the $\mathrm{TiO}_{2}$.

The surface roughness of titanium and its alloys have influence on the osseointegration speed and biomechanical fixation ${ }^{28,29}$. Studies indicate that the adhesion of bodily tissue cells increases when the surface roughness decreases ${ }^{30}$ due to a better wetting effect of the cells.

Based on the presented results, the $\mathrm{TiO}_{2}$ formed on the surface of NiTi from the heat treatment is appropriate for applications that seek biocompatibility. Since, according to Y. Arima et al. ${ }^{31}$, cellular adhesion is determined primarily by the surface wettability and the cells adhere well to hydrophilic surfaces.

According to V. Belaud ${ }^{32}$ a less rough surface is associated with a low surface energy, which decreases the droplet 


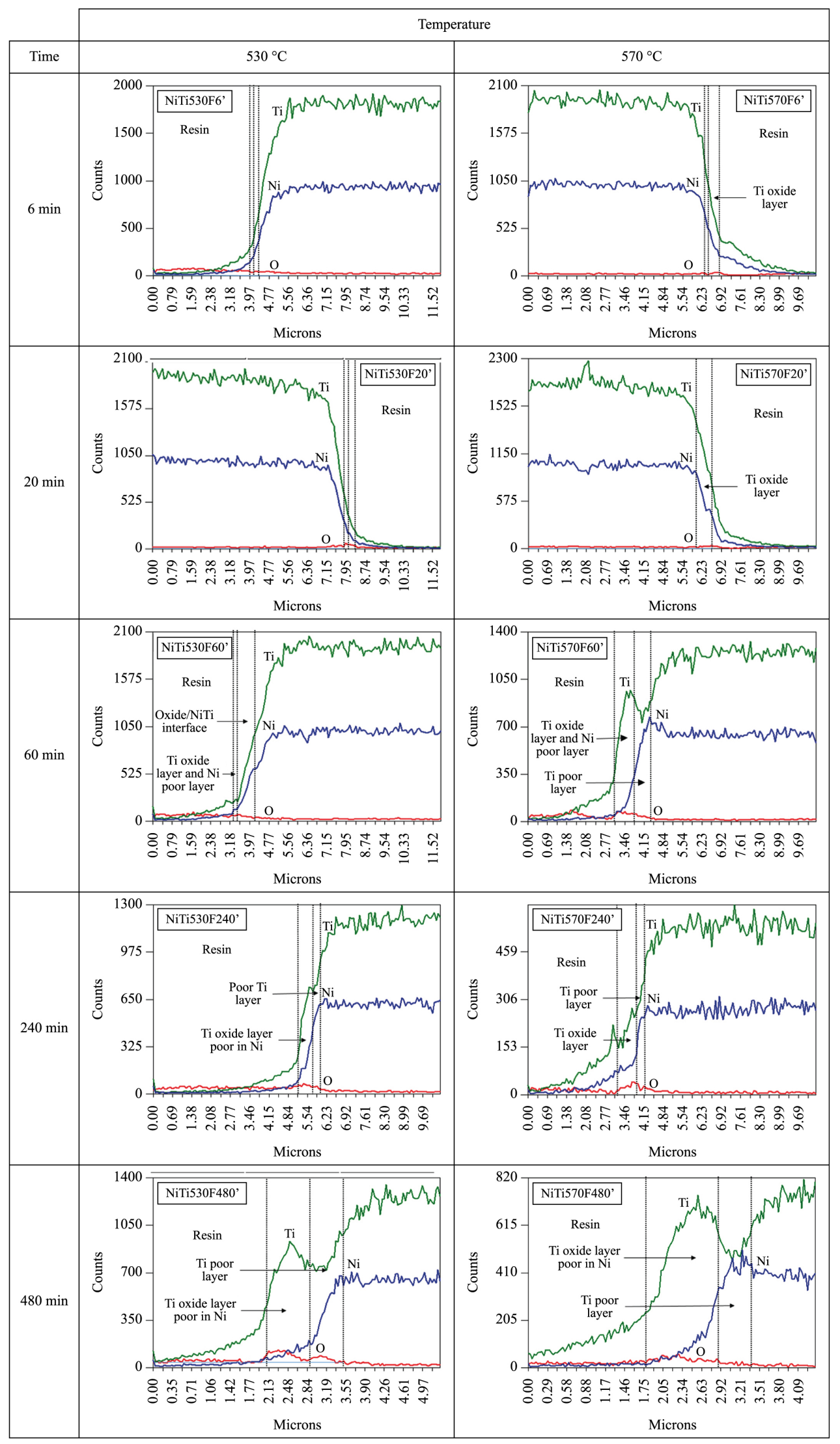

Figure 6. EDS samples exposed to different temperatures. 


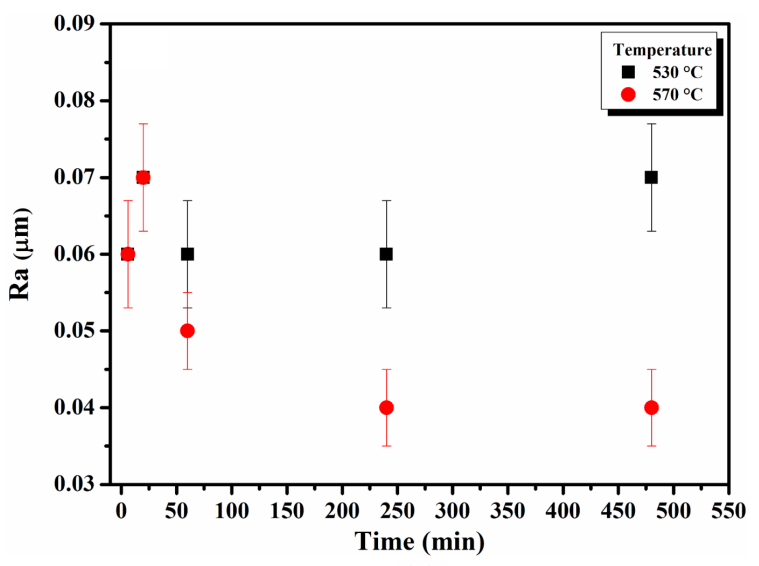

(a)

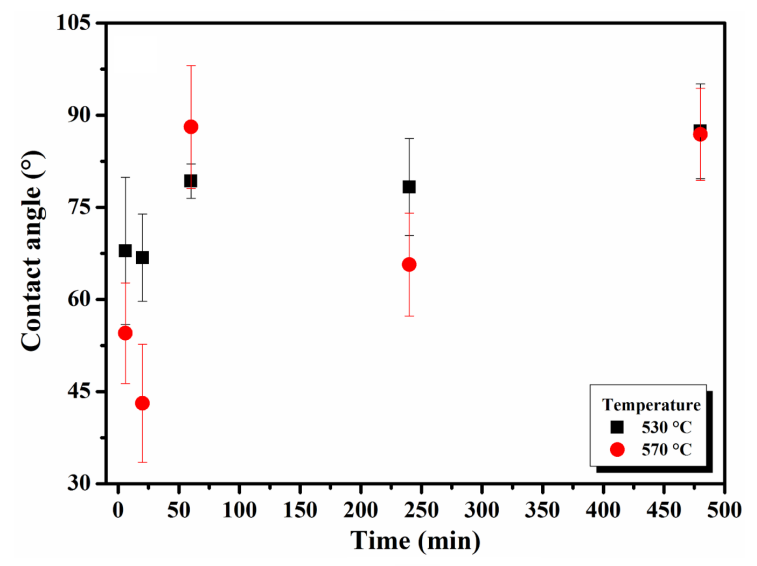

(b)

Figure 7. Roughness values (a) and contact angle (b) of the surface of the NiTi samples after exposure to different temperatures.

spreading and thereby increases the angle of interaction between water and the surface of the sample. The arrangement of atoms in the crystal lattice directly influences the free energy level of a surface.

As discussed above and shown in Figure 5, increasing the heat treatment time causes a change in the crystalline structure of the oxide, from the anatase to rutile phase. This transition rearranges the surface molecules and alters the level of surface free energy by decreasing its surface roughness and wettability.

\section{Conclusion}

The thermal treatment of an NiTi shape memory alloy promoted the formation of Ni-depleted $\mathrm{TiO}_{2}$. The formation of this oxide prevents direct contact of the tissue with the Ni. However, increasing the exposure time of the alloy, at moderate temperatures, promoted changes in the $\mathrm{TiO}_{2}$ which was formed.

The $\mathrm{TiO}_{2}$ formed in all samples is compact and has an increased oxide thickness with increasing exposure time,

\section{References}

1. Krone L, Mentz J, Bram M, Buchkremer H-P, Stöver D, Wagner M, et al. The potential of powder metallurgy for the fabrication of biomaterials on the basis of nickel-titanium: a case study with a staple showing shape memory behaviour. Advanced Engineering Materials. 2005; 7(7):613-619. http:// dx.doi.org/10.1002/adem.200500029.

2. Cai W, Lu XL and Zhao LC. Damping behavior of TiNi-based shape memory alloys. Materials Science and Engineering A. 2005; 394(1-2):78-82. http://dx.doi.org/10.1016/j.msea.2004.11.030.

3. Vargas ALM. Deposição e caracterização de revestimentos de $\mathrm{Ni}$-Ti e Ni-Ti/Nb para aplicações biomédicas. [Dissertation]. Porto Alegre: PUCRS; 2007.

4. Vojtech D, Fojt J, Voderová M, Novak P and Joska L. Influence of processing of shape memory niti alloy on its corrosion resistance. Metal. 2010;5:18-20.

5. Yahia H, editor. Shape memory implants. New York: Springer; 2000. http://dx.doi.org/10.1007/978-3-642-59768-8. following the parabolic growth law, being more pronounced at a temperature of $570^{\circ} \mathrm{C}$. At both temperatures $\left(530^{\circ} \mathrm{C}\right.$ and $570{ }^{\circ} \mathrm{C}$ ), increasing the exposure time of the samples promoted changing the anatase phase to the rutile phase.

Based on the achieved results, it was observed that the NiTi sample exposed at $570{ }^{\circ} \mathrm{C}$ for 480 minutes presented the lowest roughness and lowest surface hydrophobicity, when compared with the other samples. Moreover, the oxide presented a crystal structure composed mostly by the rutile phase. These results provide a better cell adhesion on the surface. Based on the literature, these characteristics indicate that the obtained oxide layer has the required properties to accelerate an osseointegration process, and it can be used for this purpose.

\section{Acknowledgements}

The presented work was performed with support of CAPES, a Brazilian government agency focused on support and evaluation of graduate education. Authors would also like to express their gratitude to the financial support of the Brazilian agencies CNPq and FAPERGS.

6. International Agency for Research on Cancer. World Health Organization. IARC Monograhs on the Evaluation of Carcinogenic Risks to Humans: Chromium, Nickel and Welding. Lyon: IARC; 1990.

7. Chen ZW. Formation and progression of die soldering during high pressure die casting. Materials Science and Engineering A. 2005; 397(1-2):356-369. http://dx.doi.org/10.1016/j. msea.2005.02.057.

8. Galio AF. Produção de implantes de titânio, via moldagem por injeção de pós de hidretos de titânio. [Dissertation]. Porto Alegre: UFRGS; 2004.

9. Lautenschlager EP and Monaghan P. Titanium and titanium alloys as dental materials. International Dental Journal. 1993; 43(3):245-253. PMid:8406955.

10. Xu C, Ma X, Shi S and Woo C. Oxidation behavior of TiNi shape memory alloy at $450-750^{\circ} \mathrm{C}$. Materials Science and Engineering A. 2004; 371(1-2):45-50. http://dx.doi.org/10.1016/ S0921-5093(03)00287-9. 
11. Firstov GS, Vitchev RG, Kumar H, Blanpain B and Van Humbeeck J. Surface oxidation of NiTi shape memory alloy. Biomaterials. 2002; 23(24):4863-4871. http://dx.doi.org/10.1016/ S0142-9612(02)00244-2. PMid:12361627.

12. Vojtěch D, Novák P, Novák M, Joska L, Fabián T, Maixner $\mathrm{J}$, et al. Cyclic and isothermal oxidations of nitinol wire at moderate temperatures. Intermetallics. 2008; 16(3):424-431. http://dx.doi.org/10.1016/j.intermet.2007.12.006.

13. Vojtěch D, Fojt J, Joska L and Novák P. Surface treatment of NiTi shape memory alloy and its influence on corrosion behavior. Surface and Coatings Technology. 2010; 204(23):3895-3901. http://dx.doi.org/10.1016/j.surfcoat.2010.05.010.

14. International Organization for Standardization - ISO. ISO 4288:1996: Geometrical Product Specifications (GPS) - surface texture: profile method - rules and procedures for the assessment of surface texture. ISO; 1996.

15. Yu X, Wang Z, Jiang Y and Zhang X. Surface gradient material: from superhydrophobicity to superhydrophilicity. Langmuir. 2006; 22(10):4483-4486. http://dx.doi.org/10.1021/la053133c. PMid:16649753.

16. Gentil V. Corrosão. São Paulo: LTC; 2003.

17. Diebold U. The surface science of titanium dioxide. Surface Science Reports. 2003; 48(5-8):53-229. http://dx.doi.org/10.1016/ S0167-5729(02)00100-0.

18. Mazare A, Dilea M, Ionita D, Titorencu I, Trusca V and Vasile E. Changing bioperformance of TiO2 amorphous nanotubes as an effect of inducing crystallinity. Bioelectrochemistry. 2012; 87:124-131. http://dx.doi.org/10.1016/j.bioelechem.2012.01.002. PMid:22341625.

19. Svetina M, Ciacchi LC, Sbaizero O, Meriani S and Vita A. Deposition of calcium ions on rutile (110): a first-principles investigation. Acta Materialia. 2001; 49(12):2169-2177. http:// dx.doi.org/10.1016/S1359-6454(01)00136-7.

20. Dulub O, Batzilln M, Solovev S, Loginova E, Alchagirov A, Madey TE, et al. Electron-induced oxygen desorption from the TiO2(011)-2x1 surface leads to self-organized vacancies. Science. 2007; 317(5841):1052-1056. http://dx.doi.org/10.1126/ science.1144787. PMid:17717178.

21. Vojtech D, Joska L and Leitner J. Influence of a controlled oxidation at moderate temperatures on the surface chemistry of nitinol wire. Applied Surface Science. 2008; 254(18):56645669. http://dx.doi.org/10.1016/j.apsusc.2008.03.014.

22. Jones DA. Principles and prevention of corrosion. 2nd ed. Upper Saddle River: Prentice Hall; 1996.
23. Ramanathan LV and Lalgudi V. Corrosão e seu controle. São Paulo: Hemus; 1988.

24. Ribbe AP, Foldes AG, Correa A, Hugenneyer C, Bauer P, Reuss F, et al. Corrosão e tratamentos superficiais. São Paulo: Associação Brasileira de Metais; 1971.

25. Gemelli E and Camargo NHA. Oxidation kinetics of commercially pure titanium. Revista Matéria. 2007;12(3). Available from: $<$ http://www.materia.coppe.ufrj.br/sarra/artigos/artigo10919/>. Access in: 16 Jul. 2015

26. Freiberg KE, Bremer-Streck S, Kiehntopf M, Rettenmayr M and Undisz A. Effect of thermomechanical pre-treatment on short- and long-term Ni release from biomedical NiTi. Acta Biomaterialia. 2014; 10(5):2290-2295. http://dx.doi.org/10.1016/j. actbio.2014.01.003. PMid:24418435.

27. Undisz A, Schrempel F, Wesch W and Rettenmayr M. Mechanism of oxide layer growth during annealing of NiTi. Journal of Biomedical Materials Research. Part A. 2012; 100A(7):17431750. http://dx.doi.org/10.1002/jbm.a.34133. PMid:22467267.

28. Cochran DL, Schenk RK, Lussi A, Higginbottom FL and Buser D. Bone response to unloaded and loaded titanium implants with a sandblasted and acid-etched surface: a histometric study in the canine mandible. Journal of Biomedical Materials Research. 1998; 40(1):1-11. http://dx.doi.org/10.1002/(SICI)10974636(199804)40:1<1::AID-JBM1>3.0.CO;2-Q. PMid:9511093.

29. Wennerberg A. The importance of surface roughness for implant incorporation. International Journal of Machine Tools \& Manufacture. 1998; 38(5-6):657-662. http://dx.doi.org/10.1016/ S0890-6955(97)00114-4.

30. Wirth C, Comte V, Lagneau C, Exbrayat P, Lissac M, JaffrezicRenault N, et al. Nitinol surface roughness modulates in vitro cell response: a comparison between fibroblasts and osteoblasts. Materials Science and Engineering C. 2005; 25(1):51-60. http:// dx.doi.org/10.1016/j.msec.2004.06.001.

31. Arima $Y$ and Iwata $H$. Effect of wettability and surface functional groups on protein adsorption and cell adhesion using well-defined mixed self-assembled monolayers. Biomaterials. 2007; 28(20):3074-3082. http://dx.doi.org/10.1016/j. biomaterials.2007.03.013. PMid:17428532.

32. Belaud V, Valette S, Stremsdoerfer G, Bigerelle M and Benayoun S. Wettability versus roughness: multi-scales approach. Tribology International. 2015; 82:343-349. http://dx.doi.org/10.1016/j. triboint.2014.07.002. 